\title{
Selection of Power Source for a Rotoslasher Matching with Small Tractor for Paddy and Cotton
}

\author{
Darekar Jyoti Anant ${ }^{1^{*}}$ and M. Veerangouda ${ }^{2}$ \\ ${ }^{1}$ Department of Farm Machinery and Power Engineering, College of Agricultural \\ Engineering, Raichur-584104, Karnataka \\ ${ }^{2}$ Department of Farm Machinery and Power Engineering, College of Agricultural \\ Engineering, Raichur-584104, Karnataka, India \\ *Corresponding author
}

\begin{tabular}{|l|}
\hline K e y w or d s \\
Small tractor, \\
Rotoslasher, Paddy, \\
Cotton \\
\hline Article Info \\
\hline Accepted: \\
15 December 2019 \\
Available Online: \\
20 January 2020 \\
\hline \hline
\end{tabular}

A B S T R A C T

Proper matching of implements with any type of tractor and the performance evaluation with its combination is very much important to minimize the expenditure in farming operations. An improper matching of tractor-implement combination produced an under loading of engine and hence higher operating costs and poor efficiency. For small farm holding, large tractors are not economical for cutting of stubbles of crops due to excessive operation cost. The main disadvantage of using large tractor is excessive waste of power and high fuel consumption. With small size tractor, it is necessary to select an implement size that is convenient to use or adequate for the operation to be done. Hence, to obtain a suitable implement according to tractor horsepower, implement size plays an important role. At present, in India, removal of plant stubbles is carried out by burning of huge quantity of stalks which causes air pollution, degradation of soil which directly or indirectly influence on human, animal and plant life. In order to assess the possibility of mechanization of cutting operation, it is necessary to develop small tractor operated rotoslasher to overcome the above problems and enhance the timeliness of operation.

\section{Introduction}

In India, most of the farmers use 45 to $60 \mathrm{~kW}$ tractors, which are over powered for small and marginal farmers. Further their price and operational cost is more and beyond the reach of many farmers. Bullock power needs replacement because of its increasing operational cost and low efficiency. Thus, for
Indian condition, mini or small tractor (10 to $20 \mathrm{~kW}$ ) may be best suited for small and marginal farmers. The production for small tractors $(\leq 15 \mathrm{~kW})$ in India is estimated as 23,436 units per annum (Anon., 2017). The ownership of small tractor costs 40 to $50 \%$ lesser than the popular tractor of medium size and requires $25 \%$ and $60 \%$ lesser costs in fuel and maintenance, respectively (Sahay, 
2008). Since, mini tractor or small tractor is a new name to Indian agriculture, it is necessary to develop various implements matching to it.

Any new developments in this aspect using mini or small tractor will reduce the drudgery of small land holders besides meeting timeliness of operations. Present sales trends of power tillers and mini tractors at 70,000 per annum and an additional 70,000 small self-propelled machines point out small holders' urge for small farm mechanization. Now-a-days mini tractors or small tractors are used for various operations especially for secondary tillage, interculture, making trenches, channel forming etc., where use of regular sized tractors is not possible. These types of small tractors are ideal for horticultural crops due to their small size, which also allows it to manoeuvre between trees in orchards. Some of the small tractors can also be used for plant protection aspects in plantation crops (Karale et al., 2014).

Burning of crop residues results in loss of plant nutrients like $\mathrm{N}, \mathrm{P}, \mathrm{K}$ and $\mathrm{S}$ which is having adverse impacts on soil properties and wastage of valuable crop residues as well as having impact on environmental pollution which is hazardous to human health and also produces greenhouse gases causing global warming. The crop residues improve the soil fertility by improving nutrient availability and enriching the organic matter content of soil. Hence, the type of slashing mechanism should be selected based on the efficiency in terms of finished dimensions of the stalk required for incorporation in the soil to facilitate quick decomposition.

The rotoslasher consists of blades pivoted horizontally on a vertical shaft and moves forward in the field. The efficiency of a rotoslasher is the ability to cut the stubble (crops or straw or stalk) into small pieces.
There is a need to develop a small tractor operated rotoslasher and evaluate its performance. Hence, keeping the above factors in view, an attempt has been made to develop a rotoslasher matching to mini tractor for shredding operation for selected crops. Hence, the following objectives have been considered for the study.

\section{Materials and Methods}

Development of small tractor operated rotoslasher in relation to soil, crop and machine parameters and results pertaining to performance evaluation of rotoslasher with different number of blades, peripheral velocity and rake angle are presented.

\section{Design a rotoslasher for small tractor}

Forward speed of small tractor operated rotoslasher was optimum at $3 \mathrm{kmh}^{-1}$ (Anon., 2012), whereas to cover 10 meter distance, the time required for rotoslasher was about 12 seconds. For evaluating the rotoslasher maximum peripheral velocity of $27 \mathrm{~m} \mathrm{~s}^{-1}$ (415 rpm) (Sridhar and Surendrakumar, 2016) with 4 number of blades was selected for determining the power required for shredding. The specifications of small tractor operated rotoslasher are presented in Table 1.

Strokes for 4 number of blades

$=415 \times 4$ number of blades

$=1660$ strokes of blade

\section{Cutting energy for paddy stubble}

The cutting energy required for paddy stubble was measured by using texture analyzer. The average values for cutting energy required for paddy stubble was $16.11 \mathrm{~mJ}$.

Area selected $=10 \mathrm{~m}^{2}$ area

Stubbles present in $1 \mathrm{~m}^{2}$ area were 16 in 
number, whereas stubble present in $10 \mathrm{~m}^{2}$ area were found to be 160 in number.

Strokes in $10 \mathrm{~m}^{2}$ area $=\frac{1660}{160}$

$=10.37$ strokes in $10 \mathrm{~m}^{2}$ area

Rice stubble cutting energy $=16.11 \mathrm{~mJ}$

Rice stubble cutting energy required for 1 hill $=16.11 \times 10.37$

$=167.06 \mathrm{~mJ}$ per hill

For 1 hill, the total energy required was found $167.06 \mathrm{~mJ}$.

For 160 numbers of hill which were present in $10 \mathrm{~m}^{2}$ area, energy required was calculated as $=167.06 \times 160$

$=26729.6 \mathrm{~mJ}$ in $10 \mathrm{~m}^{2}$ area

Energy required in $10 \mathrm{~m}^{2}$ area $=26.72 \mathrm{~J}$

For $10 \mathrm{~m}^{2}$ area, energy required for cutting paddy stubble was found $26.72 \mathrm{~J}$.

\section{Cutting energy for cotton stubble}

The cutting energy required for cotton stubble was measured by using texture analyzer. The average values for cutting energy required for cotton stubble was $130 \mathrm{~mJ}$.

Area selected $=10 \mathrm{~m}^{2}$ area

Stubbles present in $1 \mathrm{~m}^{2}$ area were 6 in number, whereas stubble present in $10 \mathrm{~m}^{2}$ area were found to be 60 in number.

Strokes in $10 \mathrm{~m}^{2}$ area

$=\frac{1660}{60}$

$=27.66$ strokes in $10 \mathrm{~m}^{2}$ area

Cotton stubble cutting energy $=130 \mathrm{~mJ}$
Cotton stubble cutting energy required for 1 stubble

$=130 \times 27.66$

$=3595.8 \mathrm{~mJ}$ per stubble

For 1 stubble, the total energy required was found $3595.8 \mathrm{~mJ}$.

For 60 numbers of stubbles which were present in $10 \mathrm{~m}^{2}$ area, energy required was calculated as

$=3595.8 \times 60$

$=215748 \mathrm{~mJ}$ in $10 \mathrm{~m}^{2}$ area

Energy required in $10 \mathrm{~m}^{2}$ area $=215.78 \mathrm{~J}$

For $10 \mathrm{~m}^{2}$ area, energy required for cutting cotton stubble was found $215.78 \mathrm{~J}$.

Energy required for cutting cotton stubble is more than paddy stubble therefore, the cotton stubble energy taken into consideration. To cover 10 meter distance, the time required for rotoslasher was about 0.2 minutes $\left(3 \mathrm{~km} \mathrm{~h}^{-1}\right)$.

Energy required for cutting cotton stubble

$=\frac{215.78}{0.2}$

$=1078.9 \mathrm{~J} \mathrm{~min}^{-1}$

$=17.98 \mathrm{~J} \mathrm{~s}^{-1}$

$=17.98 \mathrm{~W}$

To overcome the frictional losses, factor of safety taken as 1.4.

$=17.98 \times 1.4$

$=25.17 \mathrm{~W}$

To avoid the chocking and for efficient throwing of cut stubble, factor of safety taken as 1.5 .

$=25.17 \times 1.5$

$=37.76 \approx 38 \mathrm{~W}$

The weight of tractor was $590 \mathrm{~kg}$ and forward speed taken as $3 \mathrm{~km} \mathrm{~h}^{-1}$, therefore the power required to move tractor was $4823 \mathrm{~W}$. Hence, the total power required for was $4.86 \mathrm{~kW}$. 
Based on the power required by rotoslasher for shredding operation, a prime mover of suitable size available in market was selected.

Hence the prime mover of $15 \mathrm{~kW}$ tractor was selected. The total power available in prime mower was $15 \mathrm{~kW}$ but $60 \%$ of power losses at drawbar.

Therefore total power available from prime mover was $9.42 \mathrm{~kW}$.

\section{Model creation for rotoslasher}

Based on the design calculation and following the ASAE standard, the 3D model of a rotoslasher, which was attached with the small hp tractor later on has been developed as shown in Fig. 1. This rotoslasher was developed through CATIA, using CATIA software. Figure 2 and Figure 3 shows the performance evaluation of small tractor operated rotoslasher in paddy and cotton stubbles respectively.

\section{Results and Discussion}

The total power available in prime mower was $15 \mathrm{~kW}$ but $60 \%$ of power losses at drawbar. Therefore total power available from prime mover was $9.42 \mathrm{~kW}$.

Hence, the energy available for shredding at prime mower is more than energy required for shredding. The sufficient energy was available for shredding operation. Hence, the design is safe for shredding operation.

According to the power requirement, small tractor was selected as the source of power. The speed was measured by using a digital tachometer for selecting a appropriate peripheral velocity.

Table.1 Specifications of small tractor

\begin{tabular}{|c|l|c|}
\hline Sl. No. & \multicolumn{1}{|c|}{ Parameter } & Description \\
\hline $\mathbf{1 .}$ & Power source used & Small tractor \\
\hline $\mathbf{2 .}$ & Make & Kubota \\
\hline $\mathbf{3 .}$ & Model & A211N \\
\hline $\mathbf{4 .}$ & Maximum PTO power $(\mathrm{kW})$ & 15.7 \\
\hline $\mathbf{5 .}$ & Drive wheels & 4WD \\
\cline { 2 - 3 } & Type of tyres & Pneumatic and traction \\
\cline { 2 - 3 } & Size & Front $5-12$ \\
\hline & & Rear $8-18$ \\
\hline \multirow{2}{*}{} & Track width $(\mathrm{mm})$ & 700 \\
\hline $\mathbf{7 .}$ & Transmission & Gear shift, 9 forward and \\
\hline $\mathbf{8 .}$ & Min. turning radius $\left(\mathrm{with}^{-1}\right.$ brake $)(\mathrm{m})$ & 3 reverse \\
\hline & Traveling speed $\left(\mathrm{km} \mathrm{h}^{-1}\right)$ Max. & 2.1 \\
\hline
\end{tabular}




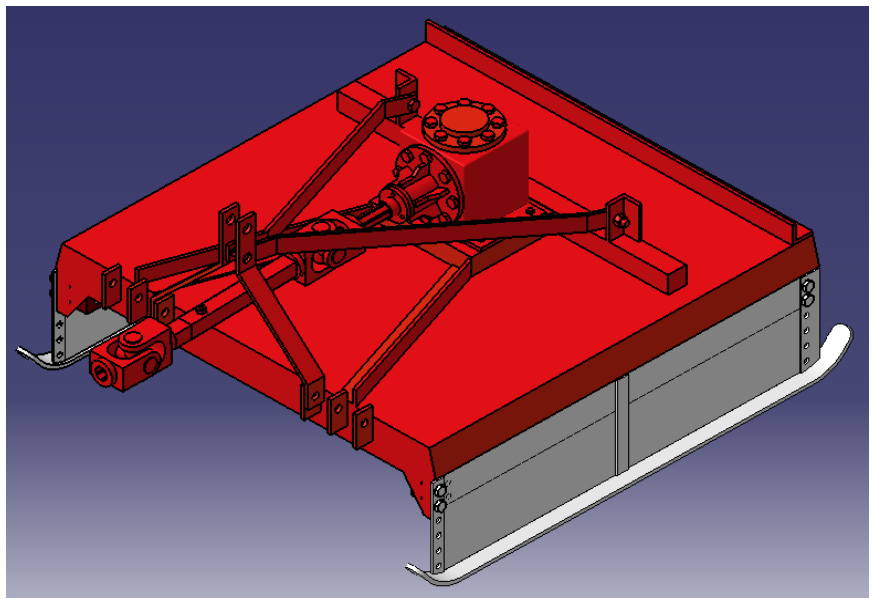

Fig.1 Overall view of small tractor operated rotoslasher developed in CATIA

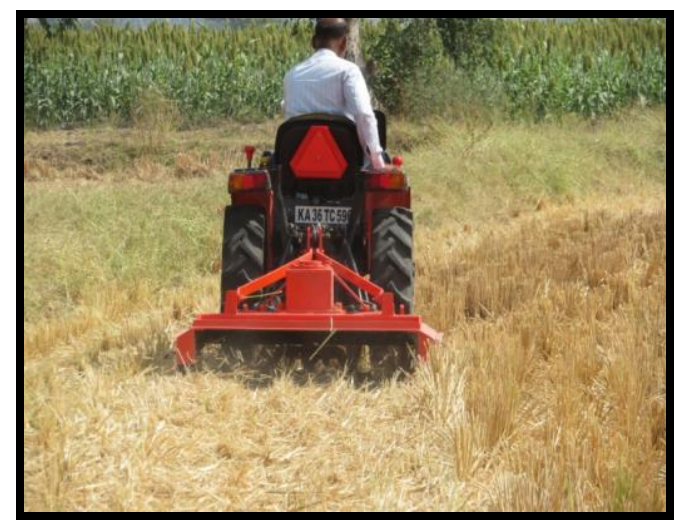

Fig.2 Performance evaluation of small tractor operated rotoslasher in paddy stubbles

\section{References}

Anonymous, 2012, Operational Manual for Kubota tractor. pp: 2-3.

Anonymous, 2017, Agricultural Research Data Book 2017. ICAR-Indian Agriculture Statistics Research Institute, Library Avenue, New Delhi. pp: 236.

Karale, D. S., Khambalkar, V.P. and Kankal, U.S., 2014, Development and testing of

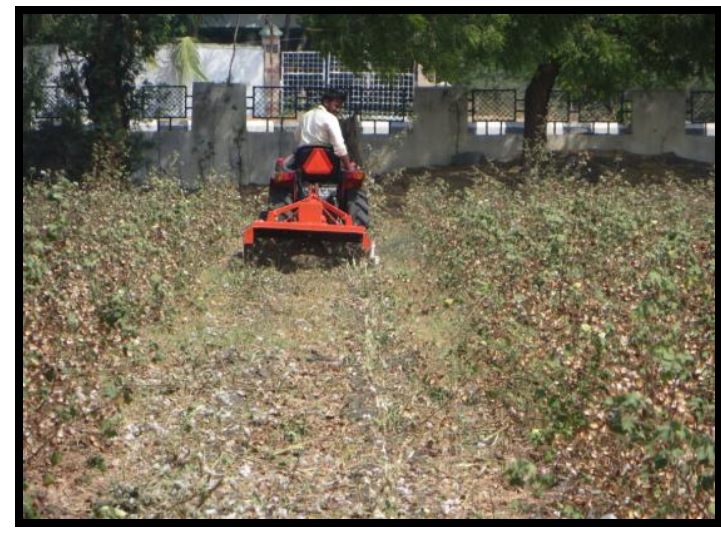

Fig.3 Performance evaluation of small tractor operated rotoslasher in cotton stubbles

tractor operated slasher. Int. J. Agric. Engg., 7(1): 160-164.

Sahay, J., 2008, Text book of elements of agricultural engineering. pp. 233-235.

Sridhar, N. and Surendrakumar, A., 2016, Shredding efficiency of agricultural crop shredder as influenced by forward speed of operation, number of blades and peripheral velocity. IJAIEM, 5(10): 129137.

\section{How to cite this article:}

Darekar Jyoti Anant and Veerangouda, M. 2020. Selection of Power Source for a Rotoslasher Matching with Small Tractor for Paddy and Cotton. Int.J.Curr.Microbiol.App.Sci. 9(01): 10651069. doi: https://doi.org/10.20546/ijcmas.2020.901.120 